\title{
Holobiont assemblages of dominant coral species (Symbiodinium types and coral species) shape Caribbean reef community structure
}

\author{
Alejandro Grajales,*, Juan Armando Sánchez ${ }^{1,2, *}$ \\ ${ }^{1}$ Departamento de Ciencias Biológicas-Facultad de Ciencias, Universidad de los Andes, Bogotá, Colombia \\ ${ }^{2}$ Laboratorio de Biología Molecular Marina - BIOMMAR, Universidad de los Andes, Bogotá, Colombia
}

\begin{abstract}
Research on coral reef community structure suggests that fine spatial-temporal stochasticity drives biodiversity patterns in this tropical marine ecosystem. The combination of a coral colony and its zooxanthella, or holobiont, should therefore be used as the community indivisible units to better understand this structure. Research in zooxanthellae (Symbiodinium) diversity has allowed the identification of specific or generalist host associations. The distribution of specific symbionts depends on both the host identity and the environmental conditions. This study determined the identity on these symbionts within hard corals communities (Scleractinia and Milleporina) at 27 sites on the upper slope habitat (mixed zone) in Cartagena, Colombia (Southwestern Caribbean Sea). Zooxanthellae identification was made with RFLPs analysis (18S, SSU, rDNA), DGGE, and DNA sequencing (ITS2, rDNA). Different combinations of coral species and their specific Symbiodinium types (holobionts) were determined as different ecological units. Taking each holobiont as a variable, a cluster community structure analysis was made and compared to the pattern obtained from using coral species alone. Different site groupings occurred for holobionts and species, where higher similarities were found using holobionts. O. annularis and $O$. faveolata, two dominant coral species, formed independently different Symbiodinium associations, depending on depth. Their symbiont preference can be under higher selection pressure than previously thought, if they act as different ecological units. (C) Acad. Colomb. Cienc. Ex. Fis. Nat. 2016.
\end{abstract}

Key words: Zooxanthellae, community structure, holobiont, Caribbean Sea, coral reefs, Symbiodinium, Scleractinia.

Conjuntos de holobiontes de especies dominantes de corales (Tipos de Symbiodinium y especies de corales) moldean la estructura comunitaria en arrecifes coralinos del Caribe

\section{Resumen}

Investigaciones de la estructura de comunidades coralinas sugieren que escalas espacio temporales cortas son responsables de patrones en ecosistemas marinos tropicales. La combinación coral y su zooxantela, u holobionte, puede ser la entidad ecológica modificada por estos factores. La estructura de la comunidad de corales podría ser mejor entendida usando el holobionte como unidad indivisible de la comunidad. Investigaciones recientes en diversidad de zooxantelas (Symbiodinium spp.) han revelado asociaciones de tipo específicas, así como generalistas dependiendo del hospedero. Su distribución depende tanto del hospedero como de las condiciones ambientales. Este estudio determino la identidad molecular de estos simbiontes en comunidades de corales duros (Scleractinia y Milleporina) en 27 localidades en el talud arrecifal superior (zona mixta) en Cartagena, Colombia. La identificación de zooxantelas se realizó mediante análisis de RFLPs (18S, SSU, rDNA, por sus siglas en inglés), DGGE y secuenciación de ADN (ITS2, rDNA). Se encontró variación intra e intercolonial, dependiendo de la especie del hospedero. Se determinaron diferentes holobiontes, como diferentes unidades ecológicas. Estas unidades correspondían a una minoría en la diversidad de especies, pero dominantes (p.ej., Orbicella spp.). Tomando cada holobionte como variable, se realizó un análisis de la estructura comunitaria y fue comparado con un análisis tomando solamente las especies de coral. Mayores similitudes entre estaciones se encontraron cuando se usaron los holobiontes. Las especies dominantes $O$. annularis y $O$. faveolata formaron en cada caso diferentes holobiontes, dependiendo de la profundidad. La preferencia hacia un tipo específico de zooxantela podría estar bajo mayor presión selectiva de lo que anteriormente se pensaba. (C) Acad. Colomb. Cienc. Ex. Fis. Nat. 2016.

Palabras clave: zooxantelas, estructura de comunidad, holobionte, Mar Caribe, arrecifes de coral, Symbiodinium, Scleractinia. 


\section{Introduction}

A fundamental question in biology is what governs species richness and abundance within communities. Since the seminal paper by Goreau (1959), Caribbean coral reef community structure is understood in terms of wave exposure and depth, a combination that makes reef zonation match geomorphological features (e.g., lagoon, back reef, reef crest, fore-reef terrace and slope). Landscape community structure studies based on either classification or ordination analyses show how coral reef sites are clustered in harmony to geomorphological features oftentimes exhibiting a continuum from shallow to deep or protected to exposed (e.g., Sánchez et al. 1997, 2005) as well as continental (neritic-siliciclastic) to oceanic (Velásquez and Sánchez, 2015). Prediction of coral community structure within a particular coral reef zone or habitat between two distant reefs is certainly a more difficult problem. The upper slope or mixed coral zone, for instance (Figure 1), shows very different community assemblages among different reefs in the Southwestern Caribbean Sea (e.g., Díaz-Pulido et al. 2004); the same happens when only sponges are taken into account (Zea, 2001). A likely explanation could be Hubbell's (2001) neutral theory, where local communities (e.g., particular reef sites) are stochastically more similar to each other depending on dispersal and connectivity links within the metacommunity. However, findings on Indopacific reefs suggest that this is not the case due to the low community structure similarity both within and among sites despite comparing the same upper slope habitat (Conolly et al. 2005, Dornelas et al. 2006), which suggest that finer spatialtemporal stochasticity drives biodiversity patterns in coral reefs. In other words, the differential species response to spatial stochastic heterogeneity seems to be structuring coral reefs within reef zones. Factors such as phylogenetic history, phenotypic plasticity (including specific symbiont preference) are possible factors driving this differential coral response.

The maintenance of hard corals in nutrient poor habitats is due to their symbiosis with zooxanthellae, Symbiodinium spp. (Dinophyceae: Suessiales), which are photosynthetic and provide corals with most of their nutrients (Muscatine \& Porter1977, Muscatine, 1990). Inside the host, zooxanthellae could be found at very high concentration levels (several million per $\mathrm{cm}^{2}$ ). While these algae have also been found in the sediment and the water column, their concentrations are much lower (Littman 2008). The first studies, based on differences at physiological and biochemical levels, revealed high diversity of symbionts (Iglesias-Prieto et al. 1992). This has been confirmed by studies based on molecular markers

\footnotetext{
*Corresponding author:

Alejandro Grajales, agrajales@amnh.org

Juan Armando Sánchez, juansanc@uniandes.edu.co

Received: October 16, 2015

Accepted: May 24, 2016
}

(Rowan \& Powers 1991, LaJeunesse 2002, McNally 1994, Santos et al. 2003). Different markers have been used to distinguish between different variants of symbionts at different resolution levels, and found that all belong to the genus Symbiodinium. RFLP analyses of the small subunit rRNA (18S) and partial chloroplast large subunit (23S)-rDNA regions (Rowan \& Powers 1991, Santos et al. 2003) have revealed at least 8 clades of the genus, named A to $\mathrm{H}$ (Pochon et al. 2006). However, the diversification at this coarse level has shown little correlation in their presence among different hosts, e.g., clade C symbionts are found diverse anthozoan hosts including corals and sea anemones as well as octocorals (LaJeunesse 2001, Rowan \& Knowlton 1995, Baker \& Rowan 1997). The ITS2 (Internal Transcribed Spacer 2) region, applied in many phylogenetic studies of diverse organisms has shown better resolution, identifying different "types" within each clade (LaJeunesse 2002). The identification of types and subtypes has guided a rapid advance in the knowledge of ecology and evolution of dinoflagellate-coral partnership.

The studies on Symbiodinium diversity based on single coral species have revealed that depending on the host, the relation could be very conservative (e.g., one single type per coral species) at different regions or depths (IglesiasPrieto et al. 2004), but the opposite is also true for other species (Rowan \& Knowlton 1995). Information from symbiont identity in many hosts of different taxa has been available (hard corals, octocorals, anemones, bivalves). For instance, in the Caribbean clades A and B are more common at shallow depths, whereas clade $\mathrm{C}$ is found at greater depths (LaJeunesse 2002). In the Pacific Ocean, on the other hand, clade $\mathrm{C}$ is the dominant symbiont in both shallow and deep reefs (Baker 2003). A compelling finding to consider zooxanthellae as driving factors for coral community structure is that the same species of scleractinian as well as soft corals exhibit significant differences in growth rates according to the zooxanthellae type (Little et al. 2004). In soft corals, it has been shown that zooxanthellae play a key role in shaping their distribution (Fabricius \& De’Ath 2008). If the holobiont is the ecological unit under selection and not the coral host and the zooxanthellae as single entities (see review in Blackall et al. 2015), coral reef community structure should be better understood using the holobiont as the community indivisible unit.

Caribbean coral reefs, with near 50 scleractinian coral species, are modest in terms of coral biodiversity compared to their Indopacific counterparts, with over 400 species. Nonetheless, Caribbean corals have less generic dominance (e.g., vs. Acropora or Pocillopora in the Pacific) and also include an overall phylogenetically more diverse assemblage of zooxanthellae (LaJeunesse 2003), which provides appealing coral-zooxanthella holobiont diversity. Caribbean reefs comprise certainly a simpler model of a coral community assemblage to examine the prediction that 

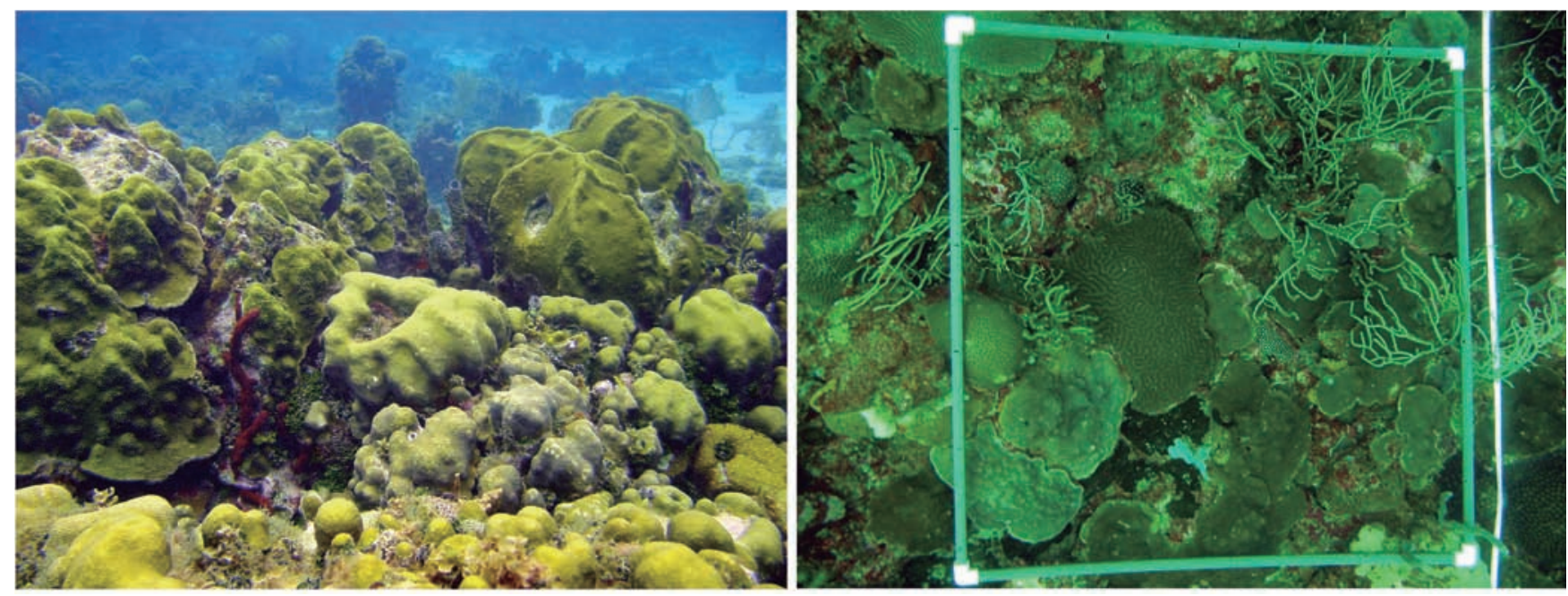

Figure 1. Upper slope, mixed coral zone in Caribbean reefs.

Left: Dominant corals in the Caribbean upper slope zone, Orbicella faveolata (far) and O. annularis (near) (Serrana Bank, Colombia). Right: $50 \mathrm{~cm}^{2}$ quadrat on the upper slope at "La montañita" reef (Barú Island, Colombia).

coral community analyses based on holobionts provide better information on community structure. The objective of this study was to use the information of symbiont types and scleractinian species coral cover in the coral reefs at the vicinity of Cartagena (Colombia) to make a holobiontbased community analysis (i.e., holobiont $=$ coral sp. + Symbiodinum type).

\section{Materials and methods}

The study area was located southwest of Cartagena, Colombia, with a $40 \mathrm{~km}$ north to south extent $\left(10^{\circ} 15^{\prime}\right.$ to $9^{\circ} 35^{\prime} \mathrm{N}, 75^{\circ} 47^{\prime}$ to $75^{\circ} 50^{\prime} \mathrm{W}$ ). Most of the modern reefs of the area have developed over ancient tertiary reef platforms and on more recent mud diapirs eroded and regrown in a step-like pattern by the continuous processes of sea level transgression-regression forming several reef steps, which were colonized by modern reefs (e.g., Vernette et al. 1992). These reefs can be considered mixed siliciclastic-carbonate environments due to their closed proximity to river mouths and estuaries, where coral genera such as Undaria, Agaricia, Porites and Orbicella are dominant (see details in Camargo et al. 2009, Cáceres \& Sánchez 2015). More or less separated coral reefs in the area are those of Barú peninsula, Salmedina Banks and Rosario islands.

During May and August of 2005, tissue samples $\left(<1 \mathrm{~cm}^{2}\right)$ of symbiotic corals were collected by SCUBA diving. The samples, limited to four per species at each site, were taken along $25 \mathrm{~m}$ length transects at 27 different sites in the upper slope or mixed corals zone (see Appendix 1 for exact locations). Tissue was removed from the edge of the colonies taking a pinch with metal tweezers $<<1 \mathrm{~cm}^{3}$. At each site, the samples for each species were obtained from portions having different orientations towards the sun, to include possible light-related zonation patterns in zooxanthellae types. The samples were kept in sealed bags with seawater and fixed after collection in $96 \%$ alcohol. Nucleic acids were extracted following the protocol by Coffroth et al. (1992) including some slight modifications. A small fraction from the tissue was transferred to a $1.5 \mathrm{ml}$ Eppendorf tube and grounded. The cells were lysed using a buffer with a CTAB (cetyltrimethyulammonium bromide) and then incubated for 1 hour at $65^{\circ} \mathrm{C}$ with proteinase $\mathrm{K}$. Then DNA was extracted by adding $300 \mu \mathrm{l}$ mixture of FCIA (phenol, chloroform and isoamyl alcohol 25:24:1: $300 \mu \mathrm{L}$ ) and centrifuging $10 \mathrm{~min}$ at $12000 \mathrm{rpm}$. The supernatant was transferred to a second tube. Then, CIA (chloroform, isoamyl alcohol 24:1: $300 \mu \mathrm{L}$ ) was added to the original tube and a second centrifugation (10 min at $12000 \mathrm{~g}$ ) with was carried out to complete the separation of the residues from the DNA. Again the supernatant was transferred to a third tube and DNA was precipitated with $800 \mu \mathrm{l}$ of $95 \%$ ethanol for $12 \mathrm{hrs}$ at $-20^{\circ} \mathrm{C}$. After a centrifugation step of $30 \mathrm{~min}$ at $12000 \mathrm{rpm}$, the alcohol was discarded and a final wash-centrifugation step (10 min at $12000 \mathrm{rpm}$ ) was made with $500 \mu \mathrm{l}$ of $70 \%$ ethanol. After discarding the alcohol, the DNA pellet was air dried and re-suspended in $30 \mu \mathrm{l}$ of TE buffer.

To identify zooxanthellae, the primers SS3Z (5'GCACTG CGGCAGTCCGAATAATTCACCGG 3'), and SS5 (5'GG TTGATCCTGCCAGTAGTCATATGCTTG 3') (Rowan \& Powers 1991) were used to amplify the nuclear small subunit ribosomal DNA (SSU 18S rDNA). The obtained fragments were digested with Taq1 restriction enzyme. Digestion products were analyzed in a $5 \% 1 \mathrm{X}$ TBE (Tris Borate EDTA) polyacrilamyde gel. The obtained patterns were compared with the Taq1 standards for each clade (e.g. Santos et al. 2003). In addition, amplification of the ITS2 region were performed using the forward primer, "ITSintfor2" (5'GAATTGCAGAACTCCGTG-3'), which 
anneals to a conserved region of the 5.8 ribosomal gene and the reverse primer "ITS2CLAMP" (5'GGGATCCATAT GCTTAAGTTCAGCGGGT-3'), modified with a 39 bp GC clamp (LaJeunesse \& Trench 2000). The PCR was carried using a touchdown amplification protocol (LaJeunesse 2001). Samples of each species at different depths were loaded onto an $8 \%$ polyacrylamide Denaturing Gradient Gel Electrophoresis-DGGE (45 \%-80 \% urea-formarmide gradient; $100 \%$ consists of $7 \mathrm{~mol} \mathrm{~L}^{-1}$ urea and $40 \%$ deionised formamide) and separated by electrophoresis for 9 hrs at 150 $\mathrm{V}$ at a constant temperature of $60^{\circ} \mathrm{C}$ (LaJeunesse 2002). Standard types were also loaded to compare them to the tested types. The gel was stained with ethidium bromide (2 $\mu \mathrm{l}, 10 \mathrm{mg} \mathrm{ml}^{-1}$ ) and then visualized in a BioRad Chemidoc XRS and the software Quantity One 4.0. Prominent bands from denaturing gels were excised and placed separately into $1.5 \mathrm{ml}$ Eppendorf tubes containing $50 \mu \mathrm{l}$ TE (Tris EDTA) buffer and heated $10 \mathrm{~min}$ at $60^{\circ} \mathrm{C}$ and stored at $-20^{\circ} \mathrm{C}$. Reamplification was later performed with $2.5 \mu \mathrm{l}$ of sample using the "ITSintfor2" forward primer, and the conserved flanking reverse primer lacking the GC clamp (Coleman et al. 1994). The PCR protocol was similar to the mentioned above, but no touchdown was used. Cycle sequencing was accomplished in both directions using 3.2 pmol of the forward and reverse amplification primers separately. Reagents and reaction conditions were as specified in the ABI Prism Big Dye Terminator Cycle Sequencing ready reaction kit (PE Applied Biosystems, Foster City, CA, USA). Reaction products were analyzed on an Applied Biosystems 310 genetic analyzer (Division of Perkin Elmer, Foster City, CA, USA).

Chromatograms were checked, edited, and sequences aligned using the software ClustalW under default settings to construct the alignment, included in the BIODEIT package (Hall 1999) and deposited in Genbank (Accession numbers EF542836-EF542845). To assess phylogenetic relationships to the sequences, maximum parsimony (MP) and maximum likelihood (ML) phylogenetic analyses were conducted on aligned data sets using PAUP 4.0b8 software under default settings (Swofford 2002). Under maximum parsimony, sequence gaps were designated as a fifth character state. A bootstrap re-sampling was conducted for 1000 replicates to assess relative branch support (Felsenstein 1985). In addition, Bayesian inference of phylogeny was done using MrBayes (Huelsenbeck \& Ronquist 2001) with 1,000,000 generations. ML and Bayesian analyses were carried out with the best-fit model obtained respectively from ModelTest and Mrmodeltest (Posada \& Crandall 1998) based on the Akaike Information Criterion (AIC).

In the same 27 transects, a set of photo belt quadrats of 0.25 $\mathrm{m}^{2}$ was taken to analyze the live coral cover for each sampled community (Figure 1). To ensure that all quadrat pictures had an area of $0.25 \mathrm{~m}^{2}$, photographs were adjusted to this area using the quadrat picture as a scale, using the software
Photoshop 7.0. Coral cover of each species was estimated using the software ImageJ (NIH). The resulting matrix contained the relative cover of each species in percentage from the total cover for each site. For each species in the analysis, information of the symbiont type was cross-corroborated using the molecular techniques explained above. Two groups of data were assembled, the first one containing the raw coral cover data (coral species), and a second one including a new holobiont variable when a coral presented symbiotic associations with different Symbiodinium types. This was performed only when differences in symbiont type were clear at the DGGE-sequence level. A cluster analysis using the software PRIMER 5 version 5.2.9 (Clarke \& Warwick 2001) was performed to each dataset (using a Bray Curtis similarity matrix and fourth root data transformation) to compare the assemblage groupings of raw coral cover vs. holobionts. A 1000 replicates bootstrap was performed on each cluster to assess the degree of statistical significance of the associations, using the software BOOTCLUS (McKenna 2003). Finally, a grouping of species was made depending on the membership to a nested or group of nested clusters (also called inverse analysis, Kaandorp 1986). The characteristic species or holobiont of each nested cluster were determined by calculating substrate cover for each cluster and then marking those which contained at least $70 \%$ of the species' total abundance (e.g., Sánchez et al. 2005). Additionally, a non-metric multidimensional scaling (nMDS) was performed with the software PRIMER 5 to each kind of data to compare the obtained grouping with environmental variables (depth, exposure - windward/ leeward and distance to the coastline).

\section{Results}

\section{Zooxanthellae identification.}

A total of 41 scleractinian species were included in the analysis. The identification of the Symbiodinium clades showed in some cases more than one RFLP pattern, an indicative that in a single colony more than one clade was present simultaneously (see Electronic Supplementary material B). Within a given species, coral colonies also presented different clades at different depths and locations. A total of 15 coral species (36.5\%) presented more than one zooxanthellate clade, both within and/or between colonies (Table 1). A total of 280 samples of coral species were analyzed; from 41 coral species, four Symbiodinium clades and at least 10 types were identified. Only one symbiont type was found in clade A (A4a) in the species Porites astreoides, Type B1 in Millepora complanata and M. alcicornis, it was presumably present in more species (Eusmilia fastigiata, Siderastrea siderea, Pseudodiploria clivosa, and Diploria labyrintiformis) A different type within clade B was detected for Porites furcata (Appendix 3b), but it was not possible to identify due to the lack of resolution of the phylogenetic tree. In terms of prevalence, clade $\mathrm{C}$ was present in most scleractinian species, either as a 
Table 1. Scleractinian hosts sampled and genetic identity of Symbiodinium spp. The identification of the symbionts types was made by RFLPs of the $18 \mathrm{~S}$ rRNA region. Identification of symbiont subtypes was made by and PCR-DGGE and ITS2 sequencing. Samples were taken in Cartagena de Indias` reefs on October 2005 For $O$. annularis and $O$. faveolata, two different associations were found at $8-12 \mathrm{~m}$ and $12-25 \mathrm{~m}$.

\begin{tabular}{|c|c|c|c|c|}
\hline \multirow[t]{2}{*}{ Host } & \multirow{2}{*}{$\begin{array}{c}\text { Nr. of } \\
\text { samples }\end{array}$} & \multicolumn{2}{|c|}{ Genetic Identity } & \multirow{2}{*}{$\begin{array}{c}\text { Depth } \\
\text { (m) }\end{array}$} \\
\hline & & $18 \mathrm{~S}$ & ITS2 & \\
\hline Acropora cervicornis & 2 & A & A3 & $8-10 \mathrm{~m}$ \\
\hline Acropora palmata & 1 & A & & $10 \mathrm{~m}$ \\
\hline Agaricia fragilis & 2 & $\mathrm{C}$ & & $20 \mathrm{~m}$ \\
\hline Agaricia undata & 2 & $\mathrm{C}$ & & $8-22 \mathrm{~m}$ \\
\hline Colpophyllia natans & 8 & C, B & & 7- $22 \mathrm{~m}$ \\
\hline Dichocoenia stokesii & 1 & $\mathrm{C}$ & & $22 \mathrm{~m}$ \\
\hline Diploria labyrinthiformis & 5 & $\mathrm{C}$ & & $7-22 \mathrm{~m}$ \\
\hline Eusmilia fastigiata & 6 & $\mathrm{C}$ & & $8-22 m$ \\
\hline Favia fragum & 2 & $\mathrm{C}$ & & $7-22 m$ \\
\hline Isophyllastrea rigida & 2 & $\mathrm{C}$ & & $10 \mathrm{~m}$ \\
\hline Isophyllia sinuosa & 2 & B & & $10 \mathrm{~m}$ \\
\hline Leptoseris cucullata & 17 & $\mathrm{C}$ & C3 & 8- $23 \mathrm{~m}$ \\
\hline Madracis decactis & 2 & $\mathrm{C}$ & & $8 \mathrm{~m}$ \\
\hline Meandrina meandrites & 5 & $\mathrm{C}$ & $\mathrm{C} 3$ & $8-12 \mathrm{~m}$ \\
\hline Meandrina meandrites & 10 & $\mathrm{C} \mathrm{B}$ & $\mathrm{C} 3, \mathrm{~B} 1$ & 12- $36 \mathrm{~m}$ \\
\hline Millepora alcicornis & 20 & A B C D & $\mathrm{A} 4, \mathrm{~B} 1, \mathrm{C} 1$ & $8-22 m$ \\
\hline Millepora complanata & 1 & A & & $8 \mathrm{~m}$ \\
\hline Mussa angulosa & 2 & C B & & $10 \mathrm{~m}$ \\
\hline Mycetophyllia aliciae & 5 & C B & & $8-22 m$ \\
\hline Mycetophyllia lamarckiana & 5 & $\mathrm{C}$ & & $10 \mathrm{~m}$ \\
\hline Orbicella annularis & 25 & A & & 8- $12 \mathrm{~m}$ \\
\hline Orbicella annularis & 25 & $\mathrm{C}$ & & 12- $22 \mathrm{~m}$ \\
\hline Orbicella faveolata & 20 & A & & 8- $12 \mathrm{~m}$ \\
\hline Orbicella faveolata & 20 & $\mathrm{CE}$ & & $12-22 m$ \\
\hline Porites astereoides & 20 & A B C & A4, B1, C3 & 8- $36 \mathrm{~m}$ \\
\hline Porites colonensis & 10 & $\mathrm{C}$ & & $8-22 \mathrm{~m}$ \\
\hline Porites porites & 5 & $\mathrm{C}$ & & 8- $22 \mathrm{~m}$ \\
\hline Pseudodiploria c1ivosa & 5 & B & B1 & 7- $22 \mathrm{~m}$ \\
\hline Pseudodiploria strigosa & 9 & $\mathrm{C}$ & & 8- $22 \mathrm{~m}$ \\
\hline Scolymia cubensis & 2 & $\mathrm{C}$ & & $20 \mathrm{~m}$ \\
\hline Scolymia lacera & 2 & $\mathrm{C}$ & & $20 \mathrm{~m}$ \\
\hline Siderastrea siderea & 10 & C, B & & 8- $22 \mathrm{~m}$ \\
\hline Solenastrea bournoni & 2 & B & & $20 \mathrm{~m}$ \\
\hline Solenastrea hyades & 5 & C,B & & $20 \mathrm{~m}$ \\
\hline Stephanocoenia intercepta & 5 & B & & $20 \mathrm{~m}$ \\
\hline Undaria agaricites & 20 & $\mathrm{C}$ & C 3 & $8-22 \mathrm{~m}$ \\
\hline Undaria tenuifolia & 15 & $\mathrm{C}$ & C3 & 8-36 m \\
\hline
\end{tabular}

single symbiont or making combinations with other clades, mainly B. The identification of specific types within clade $\mathrm{C}$ was difficult, due to the high number of types that differed in only a few base pairs or INDELS (Appendix 2). For clade C, different responses were observed, from a single symbiont type preference, to intra and intercolony variation.

The most polymorphic coral species was Porites astreoides (clades A, B, and C) followed by Millepora alcicornis (A, C, and E) and Orbicella faveolata (A, C, and E). Symbiont type determination was done for the most prevalent coral species $(n=20)$. The ITS2 identification was based on the genetic identity of prominent bands that were excised, sequenced and reloaded in consequent DGGE profiles. In some cases more than one prominent band was present (e.g., Figure 2), indicative of more than one symbiont type in the sample (LaJeunesse 2002). For most of the studied species, more than one sample was loaded in gel so we could test the variability of the symbiont type. This was helpful in determining which bands were going to be excised and sequenced. If two different bands were present in a species, both were analyzed; the same was applied if two or more

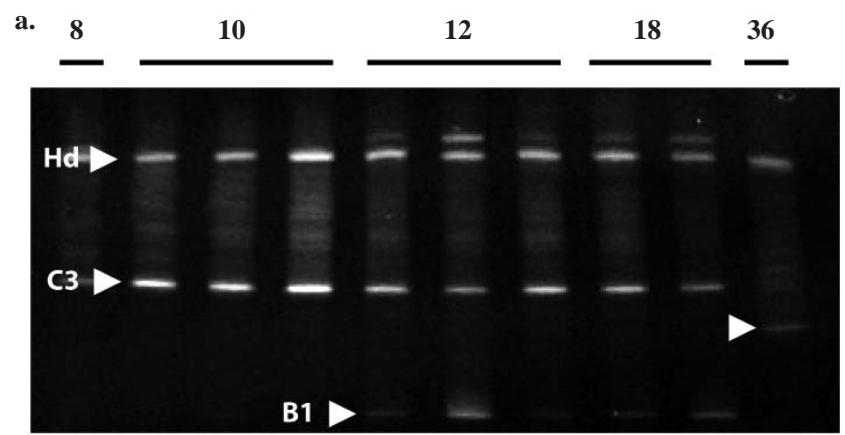

b.

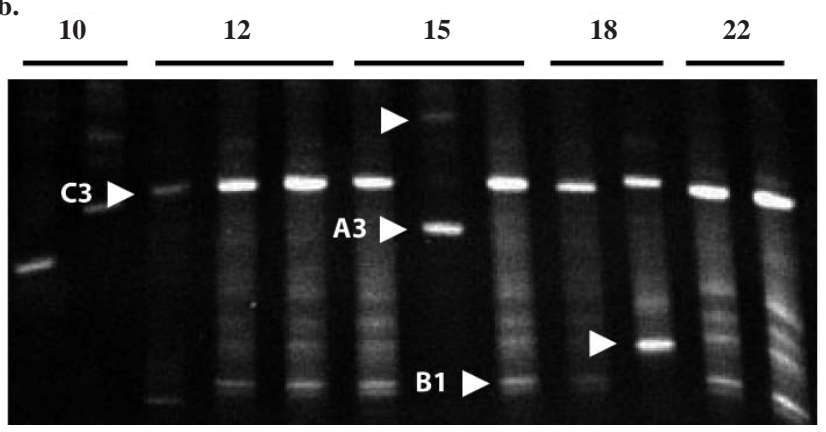

Figure 2. Examples of Symbiodinium depth zonation.

Shift over a depth gradient of DGGE profiles at various depths (m) for a coral species with and without symbiont. a. In Meandrina meandrites, the symbiont type B1 is present at depths greater than $12 \mathrm{~m}$. A different symbiont appears at $36 \mathrm{~m}$, but could not be identified at the type level. b. Millepora alcicornis profile, in which distinctive bands of different types and clades were present, but were not correlated to a depth gradient. C3 and B1 types were present in the same colony while A3 type appears as single symbiont. Hd. Heteroduplexes. 
bands were consistently repeated through the gel. The overall results were consistent with $18 \mathrm{~S}$ analysis in terms of specificity.

Three coral species showed a pattern of association to a specific symbiont depending on depth. Meandrina meandrites presented a single type, C3, in depths above $12 \mathrm{~m}$, and a combination of types C3 and B1 below that depth (Figure 2a). A different type was identified at 36 $\mathrm{m}$, but was not identified to the type level. The other two species, $O$. annularis and $O$. faveolata presented clade $\mathrm{A}$ at shallow depths, while clade $\mathrm{C}$ was present at greater depths (Table 1). Even if more than one band was present, different associations were observed with increasing depth. Other species, such as Millepora alcicornis (Figure 2b), presented high variability in symbiont type, but it was not correlated with depth. In this case, combinations of two types of symbionts, B and C, were observed, but whenever clade A was present it was as a single symbiont, indicating a possibility of competitive exclusion.

Phylogenetic analyses were carried out separately for each Symbiodinium clade, to assess the identity and relatedness of types for each sequenced sample. However, the rapid radiation of symbiont types in clades $\mathrm{B}$ and $\mathrm{C}$ made difficult the identification of some types, even at the ITS2 resolution (see also LaJeunesse et al. 2005). Clade A topology (Appendix 3a), showed the sequence of Porites astreoides symbiont closely related to type A4, but in other cases, the relatedness was not clear. The phylogenetic analysis of clade B showed a core descending from type B1, which contains the Diploria labyryntiformis sequenced type (Appendix 3b), but it was not possible to assess a precise identity. Likewise, the topology of clade $\mathrm{C}$ grouped most of the sequences of this clade within a large polytomy. This included all the species from Undaria and Agaricia, Orbicella annularis and other Porites species in which appeared the clades C1 and C3 (Appendix 3c). This was indicative that a single type was present in all these species, as seen in other studies (LaJeunesse 2002). Other types present in O. faveolata and $P$. furcata were distant from this core, related to types C7 and $C 4 / 5$, also present in the area. It the case where the topologies were not resolved, DGGE similarity was the only criterion for type determination.

\section{Coral community structure.}

A total of 41 hard coral species were found at the sampled sites and coral cover varied from 42.2 to $1.5 \%$ (Appendix $4 a)$ and the species number varied from six to twenty five. Some sites with high coral cover or species number were outside the limits of the protected area (Appendix 1). The most prevalent species in the area were Orbicella faveolata, Undaria tenuifolia, Porites astreoides, O. annularis and U. agaricites. Cluster analysis (Figure 3) showed different associations in the sampled sites. A total of 5 groups were retained as significantly similar in cluster A, including a.

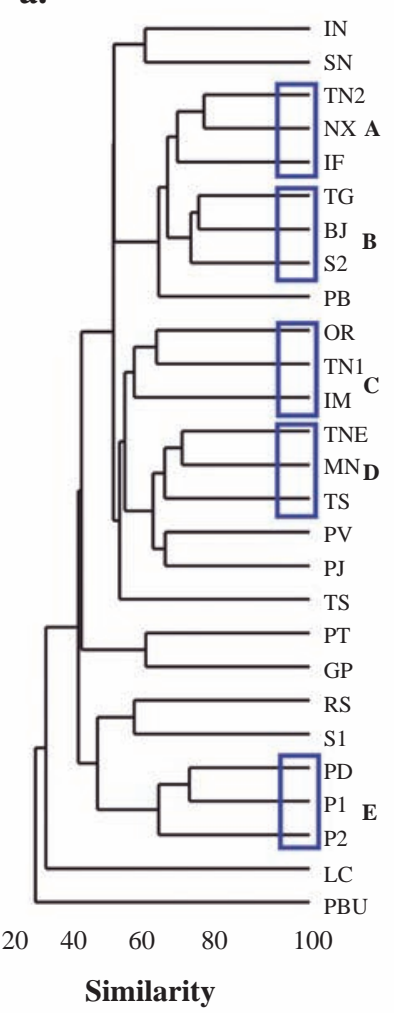

b.

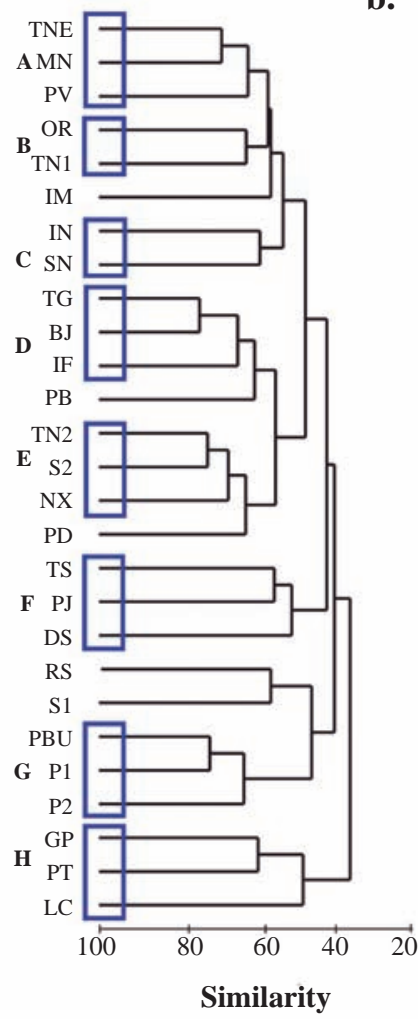

Figure 3. Cluster analysis of coral cover and holobiont zonation. Cluster grouping the sampled sites using A. Coral cover information alone and B. Holobiont information. Blue quadrants represent groups of sites significantly similar, retained after 1000 bootstrap replicates $(\mathrm{P}>0,05)$. Letters $\mathrm{A}$ to $\mathrm{E}$ on the left correspond to the retained groups in coral species cluster, while letters from A to $\mathrm{H}$ on the right correspond to the retained groups in the holobiont cluster. Two and three letter codes correspond to the sampled sites (Appendix 4a for detailed information).

15 of the 27 sampled sites. Cluster B retained 8 groups with at least $50 \%$ similarity, including 22 of the 27 sampled sites. The composition of all retained group was identical between clusters.

The community assemblage analysis presented in Tables 2 and 3 show characteristic species of each retained group in the two datasets, A and B (Coral species only and holobiont based clusters, respectively), this is, species with $>70 \%$ of their total abundance in one of the resulting groups. Cluster A retained 5 groups, in which only two species appeared as characteristic, Acropora cervicornis and Stephanocoenia intersepta, with a $100 \%$ presence (not found on other sites). Cluster B retained a total of 11 characteristic species, with abundances ranging from 85 to $100 \%$. Most of the species defining each group in cluster A were uncommon species with low cover percentages (Appendix 4b), in assemblages formed by specialist species. Meandrina meandrites holobionts, however, were differentiated among groups. One of them (with C3 symbiont type only) appeared 
Table 2. Coral species community assemblages. Boxes mark all the species characteristic of each nested group according to the cluster on the figure 2A (Kaandorp inverse analysis, including the $70 \%$ relative abundance of each species in a given cluster or group of clusters). In bold, species that are exclusive for each group (with $100 \%$ of their relative abundance). The data is presented as coverage percentage for each species.

\begin{tabular}{|c|c|c|c|c|c|}
\hline Coral species/ Group & A & B & C & D & $\mathbf{E}$ \\
\hline Acropora cervicornis & - & - & - & 0.24 & - \\
\hline Acrópora palmata & 6.03 & - & - & - & - \\
\hline Agaricia fragilis & 0.04 & - & 0.40 & 0.05 & 0.01 \\
\hline Agaricia humilis & - & 0.01 & - & 0.10 & - \\
\hline Agaricia lamarcki & - & - & 1.08 & 0.44 & - \\
\hline Agaricia undata & - & - & 2.51 & 0.23 & - \\
\hline Colpophyllia natans & 4.32 & 2.00 & - & 5.19 & 1.41 \\
\hline Dichocoenia stokesii & - & - & - & - & - \\
\hline Eusmilia fastigiata & - & 0.15 & 0.09 & 0.10 & - \\
\hline Favia fragum & 0.01 & 0.02 & - & - & - \\
\hline Isophyllastrea rigida & 0.05 & - & - & - & - \\
\hline Isophyllia sinuosa & - & - & 0.01 & - & - \\
\hline Leptoseris cucullata & - & 0.50 & 3.29 & 0.37 & 1.37 \\
\hline Mardacis decactis & 0.01 & - & 0.69 & 0.27 & - \\
\hline Madracis auretenra & - & - & - & - & - \\
\hline Meandrina meandrites & - & 0.27 & 0.06 & 1.34 & 0.01 \\
\hline Millepora alcicornis & 0.66 & 2.13 & 0.20 & 0.51 & 0.19 \\
\hline Millepora complanata & - & 0.52 & - & - & - \\
\hline Millepora striata & - & - & - & - & - \\
\hline Montastraea cavernosa & 2.78 & 1.25 & 1.83 & 4.18 & 0.06 \\
\hline Mussa angulosa & 0.03 & - & 0.71 & 17.93 & - \\
\hline Mycetphyllia aliciae & - & - & - & 0.42 & - \\
\hline Mycetophyllia lamarckiana & - & - & 0.44 & 0.32 & - \\
\hline Mycetophyllia ferox & - & - & - & 0.10 & - \\
\hline Orbicella annularis & 9.84 & 0.48 & - & 1.36 & - \\
\hline Orbicella faveolata & 42.41 & 20.76 & 36.82 & 14.35 & 2.01 \\
\hline Porites astreoides & 0.28 & 0.05 & 0.15 & 0.06 & - \\
\hline Porites colonensis & 11.44 & 6.06 & 7.73 & 5.22 & 5.98 \\
\hline Porites furcata & - & - & 0.01 & 0.18 & - \\
\hline Porites porites & 2.10 & 0.09 & 0.03 & - & 1.96 \\
\hline Pseudodiploria clivosa & 2.01 & 0.99 & - & 2.56 & - \\
\hline Diploria labrynthiformis & 0.73 & 1.50 & 0.16 & 0.81 & - \\
\hline Pseudodiploria strigosa & 18.79 & 1.60 & 1.60 & 2.29 & - \\
\hline Siderastrea siderea & 0.11 & 0.20 & 0.10 & - & - \\
\hline Scolymia cubensis & 0.28 & 1.04 & 6.17 & 1.10 & 0.05 \\
\hline Scolymia lacera & - & - & - & - & - \\
\hline Solenastrea bournoni & - & - & 0.02 & - & - \\
\hline Solenastrea hyades & - & - & - & 0.34 & - \\
\hline Stephanocoenia intersepta & - & - & - & 0.69 & - \\
\hline Undaria agaricites & 4.08 & 5.63 & 18.01 & 6.60 & 0.28 \\
\hline Undaria tenuifolia & 14.70 & 9.68 & 1.00 & 0.44 & 21.13 \\
\hline
\end{tabular}

as characteristic species (94\% of its total cover) in one of the retained groups in the cluster analysis. In contrast, the second holobiont (composed by symbiont types C3 ad B1), was more spread over different groups.

All the sites were placed on upper slopes, or on mixed zones at bank plateaus, or on lower fore-reef terraces at fringing reefs, seeking the best conditions for coral growth at each site. Nonetheless, some environmental variables such as depth, wave exposure and relative water turbidity were different among sites. The nMDS ordination analysis showed no structure or correlation between grouped sites and the measured environmental variables in any of the assemblages (Appendix 5).

\section{Discussion}

The holobiont configuration was used to make an analysis of the coral community structure, which provided better resolution at a finer level (within upper slope habitat communities). The use of holobionts (coral species and specific zooxanthellae type) led to eight significantly similar groups with at least $50 \%$ similarity. Even if only three species showed marked differences in the type of symbiont over a depth range, the high prevalence of two of them over most habitats was enough to change the similarity analysis among sites. It was evident that for the dominant reef-building corals at mixed zones, the differential species response to spatial stochastic heterogeneity was related to zooxanthellae type. Since $O$. annularis and $O$. faveolata are broadcast spawners (e.g. Sánchez et al. 1999), their larvae must acquire zooxanthellae from the environmental pool. Their Symbiodinium preference will determine their fitness (Mieog et al. 2009), depending on the availability of different free-living types of the symbionts (e.g., Porto et al. 2008). The ecological relevance of coral assemblages structured by holobionts together with the depth-related Symbiodinium preference observed in the dominant Orbicella spp. corroborates the idea on the holobiont as an ecological unit responding to environmental stochasticity. This provides a precedent for future studies, which may focus on how this unit can be a key factor driving ecological speciation via local adaptation to environmental conditions (Rowan \& Knowlton 1997, Toller et al. 2001, 2001a, 2001b Leggat et al., 2007). Another example of ecological differentiation is given by the distribution of the holobionts of Meandrina meandrites. The first holobiont (M. meandrites + C3) was identified as a characteristic species/unit in one of the retained groups in the cluster analysis. The second holobiont (M. meandrites C3 + B1), was divided into different groups. These results could also suggest ecological differentiation, showing different patterns of distribution and specialization that might have been overlooked by using the information given by the coral species information alone. Since our field survey was done before the taxonomic revision of Meandrina (Pinzón and Weil, 2011), it is possible that these associations could correspond to the paler species M. jacksoni. 
Table 3. Holobionts (Scleractinian coral species + Symbiodinium type) community assemblages. Boxes mark all the species characteristic of each nested group according to the clusters on the figure 2B (Kaandorp inverse analysis, including the $70 \%$ relative abundance of each species in determinate clusters). In bold, species that are exclusive for each group (with $100 \%$ of their relative abundance). The data is presented as coverage percentage for each species.

\begin{tabular}{|c|c|c|c|c|c|c|c|c|}
\hline Holobiont/ Group & A & B & C & $\mathbf{D}$ & $\mathbf{E}$ & $\mathbf{F}$ & G & $\mathbf{H}$ \\
\hline Acropora cervicornis & 0.24 & - & - & - & - & - & - & - \\
\hline Acrópora palmata & 0.26 & - & - & - & 6.03 & - & - & - \\
\hline Agaricia fragilis & 0.05 & 0.35 & 0.15 & - & 0.04 & - & 0.01 & - \\
\hline Agaricia humilis & 0.03 & - & 0.02 & 0.01 & - & 0.73 & - & - \\
\hline Agaricia lamarcki & 1.29 & 1.08 & - & - & - & 4.11 & - & 2.00 \\
\hline Agaricia undata & - & 2.51 & - & - & - & 0.23 & - & - \\
\hline Colpophyllia natans & 5.31 & - & 0.24 & 1.18 & 5.14 & 2.49 & 1.41 & - \\
\hline Dichocoenia stokesii & - & - & 0.00 & - & 0.00 & - & - & - \\
\hline Eusmilia fastigiata & 0.28 & 0.09 & 0.34 & 0.15 & - & 1.65 & - & 0.19 \\
\hline Favia fragum & - & 0.00 & - & 0.02 & 0.01 & - & - & - \\
\hline Isophyllastrea rigida & - & - & - & - & 0.05 & - & - & - \\
\hline Isophyllia sinuosa & - & - & - & - & - & 0.17 & - & - \\
\hline Leptoseris cucullata & 0.96 & 1.88 & 0.04 & 0.11 & 0.39 & 0.42 & 1.37 & 0.15 \\
\hline Mardacis decactis & 0.27 & 0.64 & 0.11 & - & 0.01 & 0.25 & - & 0.01 \\
\hline Madracis auretenra & - & - & - & - & - & 0.23 & - & - \\
\hline Meandrina meandrites + C3 & 0.50 & - & - & - & - & 0.02 & 0.01 & - \\
\hline Meandrina meandrites + C3 B1 & 1.32 & - & 0.46 & 0.27 & - & - & - & - \\
\hline Millepora alcicornis & 0.51 & 0.08 & 1.20 & 1.68 & 1.11 & - & 0.19 & - \\
\hline Millepora complanata & - & - & - & 0.52 & - & - & - & - \\
\hline Millepora striata & - & - & 0.03 & - & - & - & - & - \\
\hline Montastrea cavernosa & 5.09 & 1.56 & 1.58 & 2.27 & 1.76 & 5.09 & 0.06 & 0.44 \\
\hline Mussa angulosa & 0.42 & - & - & - & - & - & - & - \\
\hline Mycetphyllia aliciae & 1.24 & 0.23 & - & - & - & 0.34 & - & 0.28 \\
\hline Mycetophyllia lamarckiana & 0.06 & - & - & - & - & 0.15 & - & - \\
\hline Mycetophyllia ferox & 0.06 & 0.09 & 0.89 & 0.17 & 0.15 & - & - & - \\
\hline Orbicella annularis $+A$ & 1.01 & - & - & - & 2.67 & 0.27 & - & - \\
\hline Orbicella annularis $+C$ & - & - & - & 5.72 & 1.93 & 0.35 & - & 3.41 \\
\hline Orbicella faveolata $+A$ & 17.62 & 17.42 & 1.47 & 39.81 & - & - & 2.01 & 13.71 \\
\hline Orbicella faveolata $+C$ & - & - & - & - & 23.39 & 36.30 & - & - \\
\hline Porites astreoides & 5.20 & 7.73 & 13.18 & 5.39 & 12.11 & 3.01 & 5.98 & 2.18 \\
\hline Porites colonensis & 0.18 & 0.01 & - & - & - & - & - & - \\
\hline Porites furcata & - & 0.03 & 0.14 & 0.61 & 1.58 & - & 1.96 & - \\
\hline Porites porites & - & 0.10 & - & 0.22 & 0.08 & - & - & - \\
\hline Pseudodiploria clivosa & 0.92 & - & 0.17 & 0.35 & 2.64 & 1.64 & - & - \\
\hline Diploria labrynthiformis & 0.78 & 0.16 & - & 1.01 & 1.22 & 0.03 & - & - \\
\hline Pseudodiploria strigosa & 4.73 & 0.11 & - & 2.26 & 18.14 & - & - & - \\
\hline Siderastrea siderea & 0.96 & 0.38 & 0.22 & 1.03 & 0.29 & 3.08 & 0.05 & 0.82 \\
\hline Scolymia cubensis & - & - & 0.01 & - & - & - & - & - \\
\hline Scolymia lacera & - & 0.02 & - & - & - & - & - & - \\
\hline Solenastrea bournoni & - & - & - & - & - & 1.03 & - & - \\
\hline Solenastrea hyades & 0.69 & - & - & - & - & 0.56 & - & 0.15 \\
\hline Stephanocoenia intersepta & 0.63 & - & 0.06 & - & - & 0.26 & - & - \\
\hline Undaria agaricites & 6.91 & 13.45 & 8.72 & 6.24 & 3.47 & 13.06 & 0.28 & 0.37 \\
\hline Undaria tenuifolia & 12.25 & 1.00 & 0.19 & 7.74 & 16.64 & 3.12 & 21.13 & 0.03 \\
\hline
\end{tabular}


The distribution of Symbiodinium spp. types in a particular landscape is given by host identity and environmental variation, mainly sun irradiance (Warner et al. 2006, Finney et al. 2010). It is expected that more species present a marked shift in symbiont type at shallower locations (below $6 \mathrm{~m}$ ), because of higher light intensities and radiation could exclude some symbiont types (LaJeunesse 2002, Finney et al. 2010), or holobionts as a whole. Variation in symbiont type within a depth gradient has been reported in great detail for Orbicella annularis (Rowan et al. 1997). In contrast, Pocillopora verrucosa and Pavona gigantea, two dominant species in the eastern Pacific, harbor a distinctive symbiont that is adapted to a determined light regimen, which is likely responsible for the distribution of its respective coral host in a depth gradient (Iglesias-Prieto et al. 2004). Despite of some degree of tolerance at larval stages (e.g. Weiss et al. 2001) most coral species are adapted only to a single or few symbiont types at their adult stages. However, this specificity has been shown to be less absolute than previously thought (Silverstein, 2012), being variable depending of the local environmental conditions. Regional variation is also an important feature; the same coral species could be associated to different symbionts depending on the location and symbiont availability (LaJeunesse, 2002).

The survival of corals under different conditions is not the same for all the species. In the studied area, mono and polytypic coral-zooxanthellae associations were well represented, which suggest flexibility of some species for switching symbionts (Baker 2003). Coral species with more than one symbiont are capable of type switching if transplanted, or exposed to environmental stress (Baker et al. 2001). Even if this change is transient over a long time period (Thornhill et al. 2006, McGinley, 2012), the diversity of interaction and strategies of association of Symbiodinium supports the idea of greater ecological and evolutionary potential in flexibility. The worldwide pattern of monopolytypic species ratio shows that most coral species are associated to a single symbiont (Goulet, 2006). This scenario is alarming, since these species are, at least in the flexibility of their symbiont association, more fragile and susceptible if ocean conditions change (Baker, 2003, Putnam, 2012, Silverstein 2012). A clear prevalence of clade $C$ was found, present in $80 \%$ of the sampled species, a common pattern for scleractinians corals in other Caribbean locations (LaJeunesse, 2003). The proportion of scleractinian species sampled that harbor more than one symbiont was $35 \%$ (with a common pattern of having clade $\mathrm{C}$ and other symbiont when polytypic association was present), which is higher than any if compared to other locations in the Caribbean, with a maximum of $25 \%$ (Goulet 2006). This finding could be due to differences in sampling. Most species were sampled at various depths and different locations of the same area, a main difference with other sampled areas in the Caribbean. Other factors, such as the unique conditions of the Southwestern Caribbean reefs, e.g., high sediment loads coming from Cartagena Bay (Restrepo et al. 2006, Velásquez et al. 2011, López-Angarita et al. 2013), could also be responsible for this divergent pattern. Finally, recent studies have shown that other microorganisms such as archaea and bacteria also play a key role in the ecological dynamics on coral communities (Ainsworth et al. 2010, Kimes et al. 2010, Littman et al. 2010); however, we were not able to characterize this microbial community at the time.

The analysis of species assemblages presented two and eleven species as specialists, depending on the cluster analyzed (coral species vs. holobiont as units). In both cases this species were uncommon and presented low cover. This is a general ecological pattern (e.g., Marrugan \& Henderson, 2003), which was also found in other Southern Caribbean coral communities (e.g., Sánchez et al. 2005, López-Angarita et al. 2013). The most prevalent species such as Undaria tenuifolia, U. agaricites, Orbicella spp. and Porites astreoides did not appear as characteristic in any retained group. The imposition of environmental variables to the identified groups showed that the assemblages were not affected by a specific variable. Complementary studies including additional variables affecting coral preferences at small scale (rugosity, inclination) and time might more realistically correlate to the obtained clusters. This is the first study in which holobionts were used as units in the evaluation of coral reef assemblages. This approach resulted in greater resolution in the coral community structure, which can have important considerations on coral reef biodiversity and conservation policies.

\section{Acknowledgments}

We want to thank our sponsors Facultad de Ciencias and Department of Biological Sciences (Universidad de los Andes, Bogota, Colombia) and COLCIENCIAS (Grant \#120409-16825, J.A. Sánchez). We appreciate assistance and helpful discussions from M. P. Rozo, I. Torres, L. Lima, C. Camargo, S. Santos, T. LaJeunesse, N. Ardila and S. Restrepo. This was a joint effort and at all stages it would have been very difficult to develop without their support. Special thanks to the members of the marine molecular biology laboratory (BIOMMAR), UniAndes, who helped developing this work. The authors acknowledge the participation of local communities during the field surveys.

\section{Conflict of interests}

The authors declare no having any conflict of interest in publishing this article.

\section{Bibliography}

Ainsworth, T. D., Thurber, R. V., \& Gates, R. D. 2010. The future of coral reefs: a microbial perspective. Trends in Ecology \& Evolution, 25 (4): 233-240.

Baker AC. 2003. Flexibility and specificity in coral-algal symbiosis: diversity, ecology and biogeography of Symbiodinium. Annual Reviews of Ecology and Systematics. 34: 661-689. 
Baker AC, Rowan R. 1997. Diversity of symbiotic dinoflagellates (zooxanthellae) in scleractinian corals of the Caribbean and Eastern Pacific. Proceedings of the Eighth International Coral Reef Symposium. 2: 1301-1306.

Blackall LL, Wilson B, \& van Oppen MJ. 2015. Coral-The World's Most Diverse Symbiotic Ecosystem. Molecular Ecology (in press).

Cáceres SM, \& Sánchez JA. 2015. Growth strategies of an abundant reef-building coral in the southern Caribbean (Undaria tenuifolia). Revista de la Academia Colombiana de Ciencias Exactas, Físicas y Naturales. 39 (152): 348-357.

Camargo C, Maldonado J, Alvarado E, Moreno-Sánchez R, Mendoza S, Manrique N, Mogollón, A, Osorio J, Grajales A, Sánchez JA. 2009. Community involvement in management for maintaining coral reef resilience and biodiversity in southern Caribbean marine protected areas. Biodiversity \& Conservation. 18: 935-956.

Clarke KR, Warwick RM. 2001. Change in marine communities: an approach to statistical analysis and interpretation. 2nd edition. PRIMER-E: Plymouth.

Coffroth MA, Lasker, HR, Diamond ME, Bruenn, JA, Bermingham E. 1992. DNA fingerprints of a gorgonian coral: A method for detecting clonal structure in a vegetative species. Marine Biology. 114: 317-325.

Coleman AW, Suarez A, Goff LJ. 1994. Molecular delineation of species and syngens in volvocacean green algae (Chlorophyta). Journal of Phycology. 30: 80-90.

Connolly SR, Hughes TP, Bellwood DR, Karlson RH. 2005 Community Structure of Corals and Reef Fishes at Multiple Scales. Science. 2005; 309 (5739): 1363-5. doi: 10.1126/ science.1113281 PMID: 16123298

Díaz-Pulido G, Sánchez JA, Zea SE, Garzón Ferreira J. 2004. Esquemas de distribución espacial en la comunidad bentónica de arrecifes coralinos continentales y oceánicos del Caribe colombiano. Revista de la Academia de CienciasColombia. 108: 337-347.

Dornelas M, Connolly SR, Hughes TP. 2006. Coral reef diversity refutes the neutral theory of Biodiversity. Nature. 440: 80-82.

Fabricius KE, De'ath G. 2008. Photosynthtic symbionts and energy supply determine octocoral biodiversity in coral reefs. Ecology. 89 (11): 3163-73. ISI:000261053500020.

Finney JC, Pettay DT, Sampayo EM, Warner ME, Oxenford HA, \& LaJeunesse TC. 2010. The relative significance of host-habitat, depth, and geography on the ecology, endemism, and speciation of coral endosymbionts in the genus Symbiodinium. Microbial Ecology. 60 (1): 250-263.

Felsestein J. 1985. Confidence limits on phylogenies: an approach using the bootstrap. Evolution. 39: 783-791.

Goreau TF. 1959. The ecology of Jamaican coral reefs: 1. Species composition and zonation. Ecology. 40: 67-90.

Goulet TL. 2006. Most coral may not change their symbionts. Marine Ecology Progress Series. 321: 1-7.
Hall TA. 1999. BioEdit: a user-friendly biological sequence alignment editor and analysis program for Windows 95/98/NT. Nucleic Acids Symposium Ser. 41: 95-98.

Hubbell SP. 2001. The unified neutral theory of biodiversity and biogeography, Princeton University Press.

Huelsenbeck JP, Ronquist F. 2001. MrBAYES: Bayesian inference of phylogeny. Bioinformatics. 17: 754-755

Iglesias-Prieto R, Beltran VH, LaJeunesse TC, Reyes- Bonilla H, Thome PE. 2004. Different algal symbionts explain the vertical distribution of dominant reef corals in the eastern Pacific. Proceedings of the Royal Society London B. 271: 1757-1763.

Iglesias-Prieto R, Matta JL, Robins WA \& Trench RK. 1992. Photosynthetic response to elevated temperature in the symbiotic dinoflagelate Symbiodinium microadriaticum in culture. Proceedings of the National Academy of Science. USA 89: 10302-10305.

Kaandorp JA.1986 Rocky substrate communities of the infralitoral fringe of the Bulonnais coast, NW France. A quantitative survey using cluster analysis. Marine Biology. 92: 255- 265.

Kimes NE, Van Nostrand JD, Weil E, Zhou J, \& Morris PJ. 2010. Microbial functional structure of Montastraea faveolata, an important Caribbean reef-building coral, differs between healthy and yellow-band diseased colonies. Environmental microbiology. 12 (2): 541-556.

LaJeunesse TC. 2005 Species radiations of symbiotic dinoflagellates in the Atlantic and Indo-Pacific since the Miocene-Pliocene transition. Molecular Biology and Evolution. 22: 570-581.

LaJeunesse TC, Loh WKW, van Woesik R, Hoegh-Guldberg O, Schmidt GW, Fitt WK. 2003 Low symbiont diversity in southern Great Barrier Reef corals relative to those of the Caribbean. Limnology and Oceanography. 48: 2046-2054.

LaJeunesse TC, Loh WKW, van Woesik R, Hoegh-Guldberg O, Schmidt GW, Fitt WK. 2003 Low symbiont diversity in southern Great Barrier Reef corals relative to those of the Caribbean. Limnology and Oceanography. 48, Table supplement.

LaJeunesse TC. 2002 Diversity and community structure of symbiotic dinoflagellates from Caribbean coral reefs. Marine Biology. 141: 387-400.

LaJeunesse TC. 2001. Investigating the biodiversity, ecology, and phylogeny of endosymbiotic dinoflagellates in the genus Symbiodinium using the ITS region: In search of a “species” level marker. Journal of Phycology. 37: 866-80.

LaJeunesse TC, Trench RK. 2000 The biogeography of two species of Symbiodinium (Freudenthal) inhabiting the intertidal sea anemone, Anthopleura elegantissima (Brandt). Biological Bulletin. 199: 126-134

Leggat W, Ainsworth T, Bythell J, Dove S, Gates, R, HoeghGuldberg O, Iglesias-Prieto R, and Yellowlees D. 2007. The hologenome theory disregards the coral holobiont. Nature Reviews Microbiology. 5 (10). 
Little AF Van Oppen JH, Willis BL. 2004 Flexibility in Algal Endosymbioses Shapes Growth in Reef Corals Science. 304: 1492-1494

Littman RA, van Oppen MJ, Willis BL. 2008. Methods for sampling free-living Symbiodinium (zooxanthellae) and their distribution and abundance at Lizard Island (Great Barrier Reef). Journal of Experimental Marine Biology and Ecology. 2008 Sep 12; 364 (1): 48-53.

Littman RA, Bourne DG, \& Willis BL. 2010. Responses of coral-associated bacterial communities to heat stress differ with Symbiodinium type on the same coral host. Molecular Ecology. 19 (9): 1978-1990.

López-Angarita J, Moreno-Sánchez R, Maldonado J, JA Sánchez. 2013. Evaluating linked social-ecological systems in Marine Protected Areas. Conservation Letters. 7: 241252. DOI: $10.1111 /$ conl.12063

Marrugan AE, Henderson PA. 2003 Exploring the excess of rare species in natural species abundance distributions. Nature 422: 714-716.

McGinley MP, Aschaffenburg MD, Pettay DT, Smith RT, LaJeunesse TC, \& Warner ME. 2012. Symbiodinium spp. in colonies of eastern Pacific Pocillopora spp. are highly stable despite the prevalence of low-abundance background populations. Marine Ecology Progress Series. 462: 1-7.

McKenna Jr JE. 2003. An enhanced cluster analysis program with bootstrap significance testing for ecological community analysis. Environmental Modelling \& Software. 18: 205-220.

McNally KL, Govind NS, Thome PE, Trench RK. 1994 Small subunit ribosomal DNA sequence analyses and a reconstruction of the inferred phylogeny among symbiotic dinoflagellates (Pyrrophyta). Journal of Phycology. 30: 316-329.

Mieog JC, Olsen JL, Berkelmans R, Bleuler-Martinez SA, Willis BL, van Oppen MJ. 2009 The roles and interactions of symbiont, host and environment in defining coral fitness. PLoS One. 4 (7): e6364.

Muscatine L. 1990. The role of symbiotic algae in carbon and energy flux in reef corals. Coral Reefs. 25: 1-29.

Muscatine L, Porter JW. 1977. Reef corals: mutualistic symbioses adapted to nutrient-poor environments. Bioscience. 27: 454-460.

Pinzón JH., Weil E. 2011. Cryptic species within the Atlantic-Caribbean genus Meandrina (Scleractinia): a multidisciplinary approach and description of the new species Meandrina jacksoni. Bulletin of Marine Science. 87 (4): 823-853.

Pochon X, Montoya-Burgos JI, Stadelmann B, Pawlowski J. 2006. Molecular phylogeny, evolutionary rates, and divergence timing of the symbiotic dinoflagellate genus Symbiodinium. Molecular phylogenetics and Evolution. 38 (1): 20-30.

Porto I, Granados C, Restrepo JC, Sánchez JA. 2008. Macroalgal-associated dinoflagellates belonging to the genus Symbiodinium in Caribbean Reefs. PLoS ONE. 3: e2160.
Posada D, Crandall KA. 1998. Modeltest: testing the model of DNA substitution. Bioinformatics. 14 (9): 817-818.

Putnam HM, Stat M, Pochon X, \& Gates RD. 2012. Endosymbiotic flexibility associates with environmental sensitivity in scleractinian corals. Proceedings of the Royal Society of London B: Biological Sciences, rspb20121454.

Restrepo JD, Zapata P, Díaz JM., Garzón-Ferreira J, García CB. 2006 Fluvial fluxes into the Caribbean Sea and their impact on coastal ecosystems: The Magdalena River, Colombia. Global and Planetary Change. 50: 33-49.

Rowan R, Knowlton N, Baker AC, Jara J. 1997. Landscape ecology of algal symbiont communities explains variation in episodes of coral bleaching. Nature. 388: 265-269.

Rowan R, Knowlton N. 1995. Intraspecific Diversity and Ecological Zonation in Coral-Algal Symbiosis. Proceedings of the National Academy of Science USA. 92: 2850-2853.

Rowan R \& Powers DA.1991. A molecular genetic identification of zooxanthellae and the evolution of animal-algal symbioses. Science. 251: 1348-1351.

Sánchez JA, Pizarro V, Acosta AR, Castillo P, Herron P, Marines JC, Martines P, Orozco C. 2005. Evaluation coral ref. Benthic communities in remote Caribbean atolls (Quitasueño, Serana and Roncador banks) to recommend marine-protected areas for the seaflower biosphere reserve. Atoll Research Bulletin. 531: 1-65.

Sánchez JA, Zea S \& Díaz JM. 1997. Gorgonian communities of two contrasting environments from oceanic Caribbean atolls. Bulletin of Marine Science. 61 (2): 61-72.

Santos SR, Kinzie III RA, Sakai CK \& Coffroth MA. 2003. Molecular Characterization of Nuclear Small Subunit (18S)-rDNA pseudogenes in a symbiotic dinoflagellate (Symbiodinium, Dinophyta). Journal of Eukaryote Microbiology. 50: 417-421.

Silverstein RN, Correa AM, Baker AC. 2012. Specificity is rarely absolute in coral-algal symbiosis: implications for coral response to climate change. Proceedings of the Royal Society of London B: Biological Sciences. 279 (1738): 2609-2618.

Swofford, DL. 2002. PAUP*. Phylogenetic Analysis Using Parsimony (*and Other Methods). Version 4. Sinauer Associates, Sunderland, Massachusetts.

Thornhill DJ, LaJeunesse TC, Kemp DW, Fitt WK, Schmidt GW. 2006. Multi-year, seasonal genotypic surveys of coralalgal symbioses reveal prevalent stability or post-bleaching reversion. Marine Biology. 148: 711-722.

Toller WW, Rowan R, Knowlton N. 2001a Zooxanthellae of the Montastrea annularis species complex: patterns of distribution of four taxa of Symbiodinium across different reefs and across depths. Biological Bulletin. 201: 348-359.

Toller WW, Rowan R, Knowlton N. 2001b. Repopulation of zooxanthellae in Caribbean corals Montastrea annularis and Montastrea faveolata following experimental and disease induced bleaching. Biological Bulletin. 201: 360-373. 
Velásquez J, López-Angarita J, JA Sánchez. 2011. Benthic foraminifera as indicators of ecosystem resilience in protected and non-protected coral reefs of the Southern Caribbean. Biodiversity \& Conservation. 20: 3591-3603. doi: 10.1007/s10531-011-0152-7

Velásquez J, Sánchez, JA. 2015. Octocoral Species Assembly and Coexistence in Caribbean Coral Reefs. PloS ONE. 10: e0129609

Vernette G, Mauffret A, Bobier C, Briceno L, Gayet J. 1992. Mud diapirism, fan sedimentation and strike-slip faulting, Caribbean Colombian margin. Tectonophysics. 202: 335-349.

Warner ME, LaJeunesse TC, Robinson JD, Thur R.M. 2006. The ecological distribution and comparative photobiology of symbiotic dinoflagellate from reef corals in Belize: Potential implications for coral bleaching. Limnology and Oceanography 51 (4): 1887-1897.

Weiss, VM, Reynolds WS, Deboer MD, Krupp DA. 2001. Hostsymbiont specificity during onset of symbiosis between the dinoflagellates Symbiodinium spp. and planula larvae of the scleractinian coral Fungia scutaria. Coral reefs. 20 (3): 301-308

Zea S. 2001. Patterns of sponge (Porifera, Demospongiae) distribution in remote, oceanic reef complexes of the southwestern Caribbean. Rev. Acad. Colomb. Cienc. 25 (97): 579-592. 